EKONOMIA I FINANSE

DOI: $10.18276 /$ sip.2019.55-01

\author{
Beata Bieszk-Stolorz* \\ Krzysztof Dmytrów ${ }^{* *}$ \\ Uniwersytet Szczeciński
}

\title{
THE ASSESSMENT OF EFFECTIVENESS OF FORM OF PROFESSIONAL ACTIVISATION IN POLAND WITH RESPECT TO VOIVODESHIPS
}

\begin{abstract}
Professional activisation of the unemployed and reduction of structural mismatches in the labour market are the main objectives of employment programmes implemented in Poland by labour offices. For assessment of effectiveness of realised forms of professional activisation the cost of participation in the form of activisation is calculated, as well as the coefficients of cost and employment effectiveness. The aim of the article is to assess the effectiveness of the use by poviat labour offices of funds from the Labour Fund in the years 2008-2017 for financing basic forms of professional activisation. The assessment of effectiveness was done on the basis of the map: cost effectiveness - employment effectiveness. The study indicated that the effectiveness of the use of funds in individual voivodeships was diversified.
\end{abstract}

Keywords: forms of professional activisation, cost of participation, cost and employment effectiveness

* ORCID ID: 0000-0001-8086-9037,E-mail: beata.bieszk-stolorz@usz.edu.pl

** ORCID ID: 0000-0001-7657-6063,E-mail: krzysztof.dmytrow@usz.edu.pl 


\section{Introduction}

Big expenses connected with leading active labour market policy make necessary to perform research on effectiveness of their instruments and evaluation studies. These analyses are to a high degree based on the scientific output of the Nobel Memorial Prize in Economic Sciences laureate, James Heckman (Heckman, Lalonde, Smith, 1999). Due to different situation on the labour markets in the United States and European countries, research on effectiveness focussed on different aspects of the labour market policy. In the USA usually the income effects of active employment programmes are analysed. On the contrary, in the European Union the employment effects are usually analysed. After accession of Poland into the European Union, the scope of professional activisation of the unemployed persons increased. The main aims of the amendments are: increase of the professional activisation of persons in difficult situation, extending access to labour market services, promotion of the lifelong learning and modification of the system of unemployment benefits. One of main goals of these changes is increase of motivation for job seeking. These activities increase the probability and intensity of finding jobs by the unemployed persons (Bieszk-Stolorz, 2017). Applied by the labour offices instruments affect the two sides of the labour market: supply and demand. The following instruments can be considered as supply-oriented: on-the-job training, traineeships and professional preparation. Intervention works, public works, socially useful works and funds for the unemployed to take up business activity and for equipping the job for the unemployed person constitute a group of demand-oriented instruments - the subsidised employment (Wiśniewski, Zawadzki, 2010). From the social point of view it is important to employ as many looking for job persons as possible. On the contrary, from the point of view of institutions financing the active programmes of support the evaluation of disbursement of funds is essential. To this end, the effectiveness of the actions taken is examined. This is an important tool for measuring performance. In theory of economics we can distinguish the two aspects of effectiveness. The first is to strive for maximum efficiency, i.e. to achieve the highest possible output from a certain amount of inputs. The second is related to the resources saving, which means achieving the specified results with the lowest possible outlays (costs) (Knapińska, 2015). The active labour market policy in Poland brings positive effect consisting of only on temporary reduction of unemployment (Rękas, 2013).

The goal of the article is the assessment of effectiveness of forms of professional activisation in Poland with respect to voivodeships. In the first stage of the analysis 
the three indicators were compared: cost of activisation of the unemployed person, cost and employment effectiveness for Poland. Next, using the map: cost effectiveness - employment effectiveness the effectiveness of forms of activisation in particular voivodeships was compared.

\section{Basic forms of professional activisation}

The catalogue of basic forms of professional activisation is determined by the minister in charge of labour matters. In the years 2006-2017 this catalogue evolved. Due to the auxiliary character or insignificant share in expenditure incurred on a national scale, in years 2006-2017 some forms of support did not become the basic forms of professional activisation (for example activation allowance, scholarships in the period of continuing education, reimbursement of travel and accommodation costs, reimbursement of social security contributions to farmers made redundant from work, training loans). Table 1 presents the basic forms of professional activisation in years 2006-2017.

Table 1. Basic forms of professional activisation in Poland in years 2006-2017

\begin{tabular}{|l|c|c|c|}
\hline \multicolumn{1}{|c|}{ Basic forms of professional activisation } & 2006-2009 & 2010-2013 & $2014-2017$ \\
\hline trainings & + & + & + \\
\hline employment in intervention works & + & + & + \\
\hline employment in public works & + & + & + \\
\hline internship with an employer & + & + & + \\
\hline granting the unemployed one-off funding for business start-ups & + & + \\
\hline $\begin{array}{l}\text { granting employers reimbursement of costs of equipment/ } \\
\text { supplementation of workstations for the unemployed } \\
\text { who are directed to those places of work }\end{array}$ & + & + \\
\hline carrying out socially useful work & + & + & - \\
\hline preparing adults for the profession in the workplace & + & - & - \\
\hline
\end{tabular}

Source: own elaboration.

Figure 1 presents the number of the unemployed persons participating, ending participation and employed after graduating participation in activisation programmes. The largest number of persons participated in trainings and internships and the least - in reimbursement of costs of equipment/supplementation of workstations. 
Figure 1. Number of unemployed persons participating, ending participation and employed after graduating participation in activisation programmes in years 2006-2017

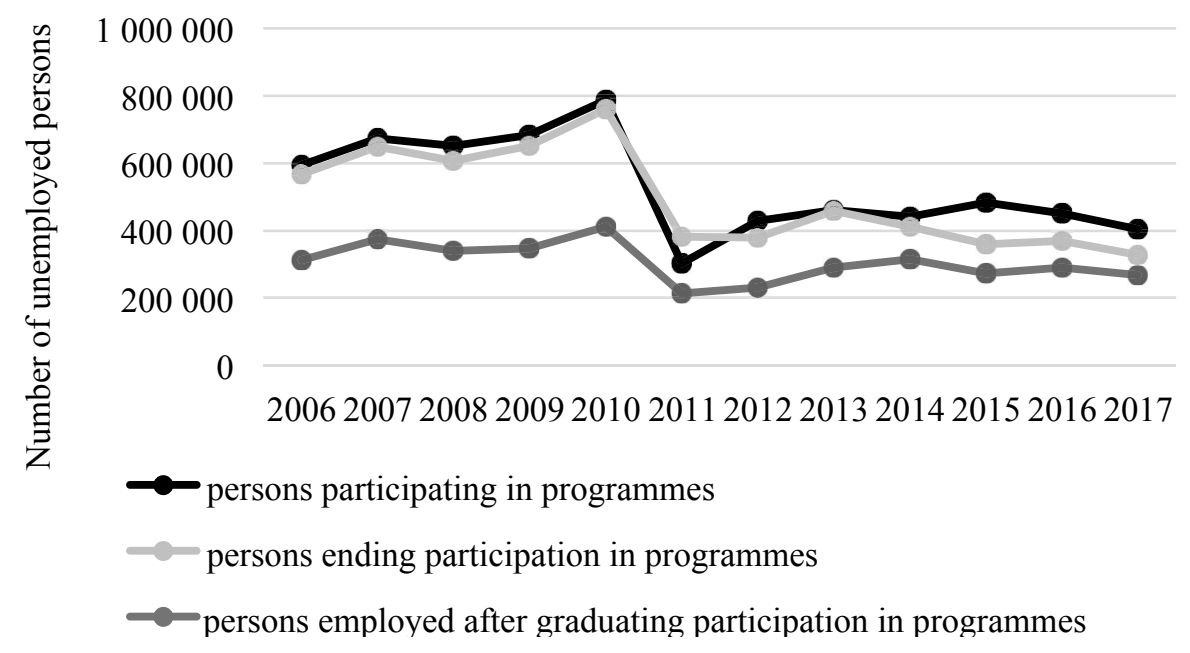

Source: own elaboration.

\section{Research methodology}

In order to assess the effectiveness of realised programmes, the cost of participation in the form of professional activisation and coefficients of cost and employment effectiveness were calculated. These coefficients are calculated for basic forms of professional activisation.

The employment effectiveness is the indicator allowing for assessment of chances of finding employment after finishing participation in a given form of professional activisation. It is calculated by means of the following formula:

$$
E E=\frac{\text { number of persons employed during or after ending participation }}{\text { number of indicated persons who ended their participation }} \cdot 100 \%
$$

Cost effectiveness allows to assess the cost of leading the unemployed person to employment. It is calculated by means of the following formula:

$$
C E=\frac{\text { amount of expenditure from the Labour Fund }}{\text { number of persons indicated as employed }}
$$


Cost of participation in a given form of activisation informs about mean cost of activisation of one person. It is calculated by means of the formula:

$$
C P=\frac{\text { amount of expenditure from the Labour Fund }}{\text { number of persons who participated in a given form of activisation }}
$$

Persons, for who in given year the expenditures from the Labour Fund are incurred are considered as participating in a given form of activisation, regardless of the period of activisation and multiple participation in the same form of activisation.

Persons, who ended their participation in a given form of activisation are these ones, who in given year ended their participation in this form of activisation financed from the Labour Fund, including persons, who ended their activisation started in previous years.

Persons, who were employed were these ones, who during or in the period of 3 months after ending their participation in a given form of activisation took a job and had worked for at least 30 days - with accordance to the data obtained from the Social Insurance Institution.

Due to the change of methodology of calculation of the employment effectiveness for basic forms of professional activisation in 2015, it is not possible to compare this coefficient directly for the year 2015 and previous years. The change of methodology referred mostly to the change of definition of ending participation and change of definition of employment (MRPiPS, 2016).

\section{Assessment of effectiveness of forms of professional activisation}

The research was based on the statistical data referring to the cost and employment effectiveness, published by the Ministry of Family, Labour and Social Policy (MRPiPS, 2019).

In years 2006-2017 there are visible significant differences between the percentages of persons participating in various activisation programmes and persons ending their participation and employed afterwards (Table 2). In the analysed period on the average slightly over $93 \%$ of persons starting their participation in programmes ended it, but only about 59\% of them found employment. In the year 2011 the percentage of persons ending their participation in various programmes is over $100 \%$. It results from the fact that large number of persons started their participation in the year 2010 and ended in 2011. 
Table 2. Percentage of persons ending their participation and employed after ending participation in programmes in years 2006-2017

\begin{tabular}{|l|c|c|}
\hline \multirow{2}{*}{ Year } & \multicolumn{2}{|c|}{ Percentage of persons } \\
\cline { 2 - 3 } & $\begin{array}{c}\text { ending their } \\
\text { participation (\%) }\end{array}$ & $\begin{array}{c}\text { employed after ending } \\
\text { participation (\%) }\end{array}$ \\
\hline 2006 & 95.54 & 52.44 \\
\hline 2007 & 96.30 & 55.58 \\
\hline 2008 & 93.11 & 52.13 \\
\hline 2009 & 95.12 & 50.61 \\
\hline 2010 & 96.27 & 52.13 \\
\hline 2011 & 126.58 & 70.48 \\
\hline 2012 & 88.38 & 53.80 \\
\hline 2013 & 99.45 & 63.00 \\
\hline 2014 & 93.29 & 71.13 \\
\hline 2015 & 74.44 & 56.49 \\
\hline 2016 & 81.97 & 64.55 \\
\hline 2017 & 81.06 & 66.45 \\
\hline
\end{tabular}

Source: own elaboration.

In connection with these differences, cost effectiveness is much higher than the cost of participation of one person in a programme (Figure 2). In years 2006-2010 high increase of the cost effectiveness (from ca. PLN 6.5 thousand to ca. PLN 13 thousand) was accompanied by relatively constant employment effectiveness on the level of about 55\%. In 2011 in comparison with the previous year, the cost effectiveness decreased significantly from ca. PLN 13 thousand to ca. PLN 9 thousand. This was related to a decrease in expenditure on the implementation of programmes for the promotion of employment (by about 64\%). Indeed, Poland was the subject to an excessive deficit procedure and, in line with the Ecofin Council recommendation (of 7 July 2009), was required to correct the general government deficit below 3\% of GDP by 2012 . Inclusion under this procedure entailed a reduction in expenditure from the Labour Fund, which is part of this sector. In the subsequent years both types of effectiveness had increasing trends. It proves better use of funds for professional activisation of the unemployed in 2011-2017.

In order to compare the costs of participation and cost effectiveness of the activisation programmes the absolute and relative differences between them were calculated (Figure 3). In years 2006-2010 the absolute difference between the costs of activisation and the cost effectiveness increased. However, the relative difference was on similar, but high level (almost 2 in 2009). In year 2017 the absolute difference was equal 3,865 PLN, or the cost effectiveness was by $50 \%$ higher than the cost 
of activisation of one person. In the same year the employment effectiveness was $82 \%$. It proves slightly better, but still high cost of leading the unemployed person to employment.

Figure 2. Cost of participation, cost and employment effectiveness of the activisation programmes in Poland in years 2006-2017

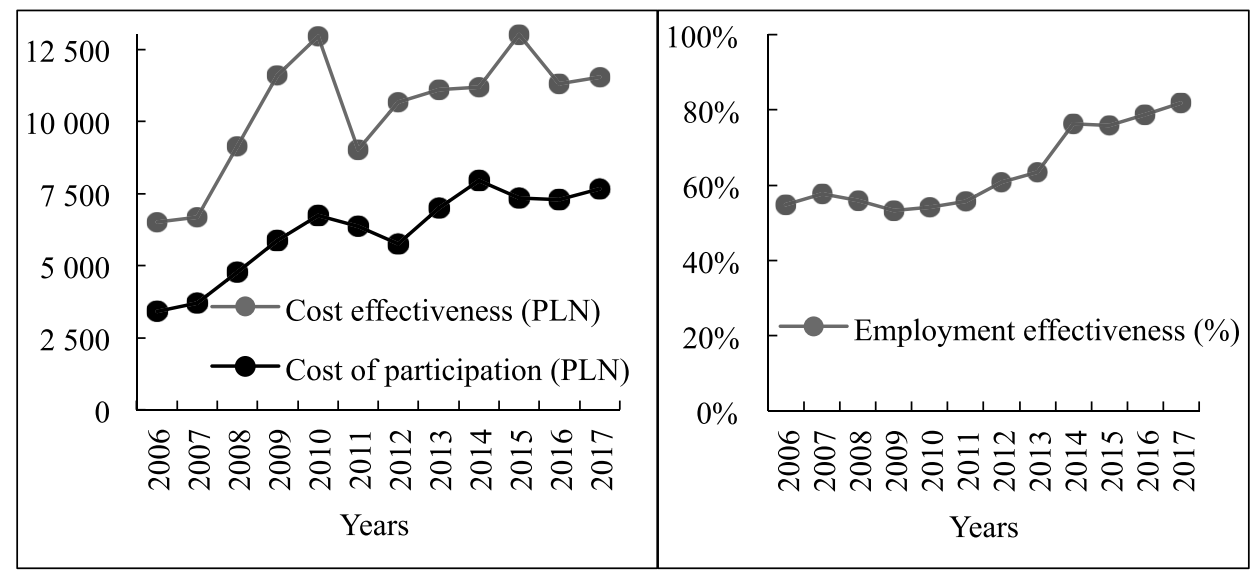

Source: own elaboration.

Figure 3. Absolute and relative differences between the cost of participation and the cost effectiveness of the activisation programmes in Poland in years 2006-2017

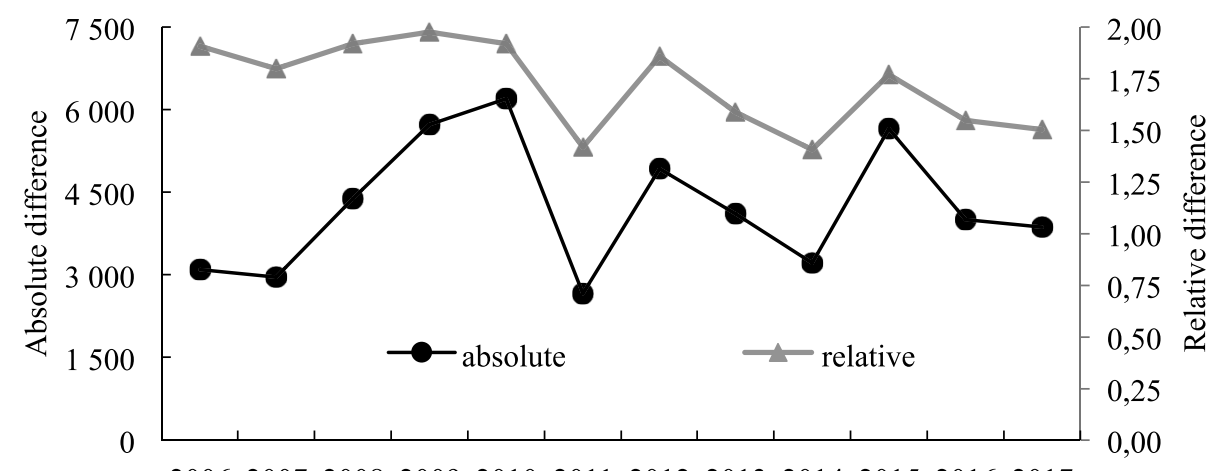

200620072008200920102011201220132014201520162017 
In order to group voivodeships with respect to the effectiveness, the maps: cost effectiveness - employment effectiveness for basic forms of professional activisation for years 2008-2017 were made ${ }^{3}$. It allowed for separation of four groups of voivodeships due to their location in relation to average effectiveness: cost and employment. Figure 4 presents the exemplary map for the year 2017. Horizontal and vertical axes constitute mean cost and employment effectiveness for Poland, respectively. These axes divided voivodeships into four groups. The best ones are in group IV, where lower value of the cost effectiveness corresponds with higher value of the employment effectiveness. The worst situation is in group II, where the cost effectiveness is high and the employment one - low. Good standing with respect to the employment effectiveness is in the group I (both types of effectiveness are high) and with respect to the cost one - in the group III (both types of effectiveness are low). However, from the point of view of the social policy the employment issue is more important, therefore better situation is in the group I. Designated groups are presented in Table 3.

Figure 4. The map: cost effectiveness - employment effectiveness in 2017

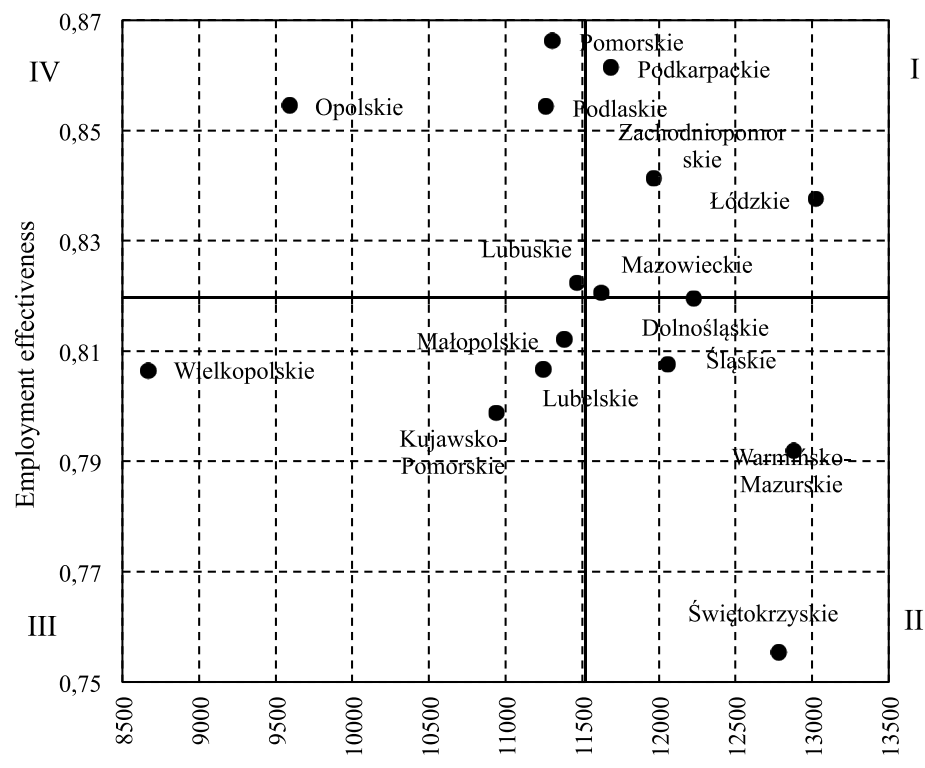

Cost effectiveness

Source: own elaboration.

3 The studies of the Ministry of Family, Labour and Social Policy do not include data for 2006-2007 concerning cost and effectiveness for voivodeships. 
With respect to accepted criteria, in the whole analysed period the best situation was in Wielkopolskie and Pomorskie voivodeships (except for the year 2013) and the worst - in Warmińsko-Mazurskie (except for the year 2016) and Małopolskie (except for the years: 2015 and 2017). Taking into account the social aspect of professional activisation, the main goal is finding a job by the unemployed persons. Therefore high value of the employment effectiveness is desirable even when the cost effectiveness is high. In years 2008-2017 such situation was in Dolnośląskie and Łódzkie voivodeships, which in the analysed period belonged mostly to the group I. The largest number of the unemployed persons is registered in the Mazowieckie voivodeship and therefore this voivodeship holds the largest resources designed for their activisation. However, in years 2008-2013 both types of effectiveness took the least favourable values (group II). The situation improved only after the year 2014. It is worth noting that the Zachodniopomorskie voivodeship was in the group of voivodeships with the best situation in years 2008-2010, 2012 and 2016. It was in the group of voivodeships with the worst situation in 2014. Authors' earlier research proved that voivodeships, in which the largest amounts of resources were destined for activisation generally used them worse and vice versa (Bieszk-Stolorz, Dmytrów, 2018).

Table 3. Division of voivodeships with respect to the forms of effectiveness against Poland (2008-2017)

\begin{tabular}{|l|c|c|c|c|c|c|c|c|c|c|}
\hline \multicolumn{1}{|c|}{ Voivodeship } & 2008 & 2009 & 2010 & 2011 & 2012 & 2013 & 2014 & 2015 & 2016 & 2017 \\
\hline Dolnośląskie & I & I & I & I & I & I & I & IV & I & I \\
\hline Kujawsko-pomorskie & III & III & III & II & III & III & III & II & III & III \\
\hline Lubelskie & II & II & II & I & I & IV & IV & IV & IV & III \\
\hline Lubuskie & IV & IV & IV & IV & III & III & I & IV & IV & II \\
\hline Łódzkie & I & IV & I & I & I & I & I & IV & I & I \\
\hline Małopolskie & II & II & II & II & II & II & II & III & II & III \\
\hline Mazowieckie & II & II & II & II & II & II & I & I & I & IV \\
\hline Opolskie & IV & III & III & III & III & III & IV & IV & IV & IV \\
\hline Podkarpackie & II & II & II & II & I & IV & IV & II & I & I \\
\hline Podlaskie & IV & II & III & I & IV & IV & IV & IV & I & IV \\
\hline Pomorskie & IV & IV & IV & IV & IV & III & IV & IV & IV & IV \\
\hline Śląskie & IV & IV & IV & II & III & II & II & II & II & II \\
\hline Świętokrzyskie & II & II & I & II & I & III & II & II & II & II \\
\hline Warmińsko-mazurskie & IV & IV & IV & IV & IV & IV & IV & IV & IV & III \\
\hline Wielkopolskie & IV & IV & IV & III & IV & III & II & I & IV & I \\
\hline Zachodniopomorskie & & & & & & & & & & \\
\hline
\end{tabular}




\section{Conclusions}

Performed analysis indicates that in years 2006-2017 the effectiveness of use of funds for financing the basic forms of professional activisation of the unemployed persons was gradually improving. The funds entrusted were best managed by the Wielkopolskie and Pomorskie voivodeships and the worst - by Warmińsko-Mazurskie and Małopolskie voivodeships. Also the Dolnośląskie and Łódzkie voivodeships should be viewed as positive. Despite high values of the cost effectiveness, the employment ones were high as well. In the year 2011 the funds destined for professional activisation of the unemployed persons were used the worst (the largest number of voivodeships was in the group II). In years 2006-2017 the percentage of persons starting and resigning from participation in selected forms of professional activisation was not high and (less than 7\%). However, percentage of persons who found employment was also low (59\%). In the analysed period the increase of the cost effectiveness was accompanied by the increase of the employment one. As long as the increase of the cost effectiveness should be considered as the negative phenomenon (from the point of view of public finances), it should be noticed that at the same time the relative difference between this effectiveness and the cost of activisation of the unemployed person decreased. All this proves that the effectiveness of activities of labour offices connected with professional activisation of the unemployed persons improved.

\section{References}

Bieszk-Stolorz, B. (2017). Cumulative Incidence Function in Studies on the Duration of the Unemployment Exit Process. Folia Oeconomica Stetinensia, 1 (17), 138-150. DOI:10.1515/foli-2017-0011.

Bieszk-Stolorz, B., Dmytrów, K. (2018). Efektywność form aktywizacji zawodowej w przekroju wojewódzkim. Wiadomości Statystyczne, 12 (691), 57-74.

Heckman, J.J., Lalonde, R.J., Smith, J.A. (1999). Chapter 31. The Economics and Econometrics of Active Labor Market Programs. Handbook of Labor Economics, 3/1, 18652097. DOI: 10.1016/S1573-4463(99)03012-6.

Knapińska, M. (2015). Efektywność polityki rynku pracy - aspekty teoretyczne i praktyczne. Prace Naukowe Uniwersytetu Ekonomicznego we Wrocławiu, 401, 187-197. DOI: 10.15611/pn.2015.401.17.

MRPiPS (2016). Efektywność podstawowych form aktywizacji zawodowej realizowanych w ramach programów na rzecz promocji zatrudnienia, tagodzenia skutków bezrobo- 
cia i aktywizacji zawodowej w 2015 roku. Warszawa: Ministerstwo Rodziny, Pracy i Polityki Społecznej.

MRPiPS (2019). Efektywność form promocji zatrudnienia i aktywizacji zawodowej. Retrieved from https://archiwum.mpips.gov.pl/praca/fundusz-pracy/efektywnosc-form-promocjizatrudnienia-i-aktywizacji-zawodowej (5.03.2019).

Rękas, M. (2013). Efektywność podstawowych form aktywizacji zawodowej w Polsce w latach 2005-2011. Zarządzanie i Finanse, 2/3 (11), 349-360.

Wiśniewski, Z., Zawadzki, K. (red.) (2010). Aktywna polityka rynku pracy w Polsce w kontekście europejskim. Toruń: Wojewódzki Urząd Pracy, Uniwersytet Mikołaja Kopernika w Toruniu.

\section{OCENA SKUTECZNOŚCI FORM AKTYWIZACJI ZAWODOWEJ W POLSCE WEDKUG WOJEWÓDZTW}

\section{Streszczenie}

Aktywizacja zawodowa bezrobotnych i zmniejszenie niedopasowań strukturalnych na rynku pracy są głównymi celami programów zatrudnienia wdrażanych w Polsce przez urzędy pracy. Do oceny skuteczności realizowanych form aktywizacji zawodowej wyznacza się koszt uczestnictwa w formie aktywizacji, współczynniki efektywności zatrudnieniowej i kosztowej. Celem artykułu jest ocena efektywności wykorzystania, przez powiatowe urzędy pracy środków z Funduszu Pracy w latach 2008-2017 na finansowanie podstawowych form aktywizacji zawodowej. Oceny skuteczności programów dokonano na podstawie mapy: efektywność kosztowa - efektywność zatrudnieniowa. Badanie wskazało na zróżnicowanie efektywności wykorzystania funduszy w poszczególnych województwach.

Słowa kluczowe: formy aktywizacji zawodowej, koszt uczestnictwa, efektywność zatrudnieniowa i kosztowa

Kody JEL: C38, J68

\section{Cytowanie}

Bieszk-Stolorz, B., Dmytrów, K. (2019). The assessment of effectiveness of form of professional activisation in Poland with respect to voivodeships. Studia i Prace WNEiZ US, 55, 11-21. DOI: 10.18276/sip.2019.55-01. 